\title{
Functional mixed cobalt and aluminum oxide coatings for environmental safety
}

\author{
M.V.Ved, N.D.Sakhnenko, A.V.Karakurkchi, T.Yu.Myrna \\ The National Technical University "Kharkiv Polytechnic Institute", \\ 2, Kyrpychova Str., 61002 Kharkiv, Ukraine
}

\author{
Received February 8, 2017
}

\begin{abstract}
Principles of plasma-electrolytic oxidation of the aluminum alloys in diphosphate electrolytes are discussed. It has been established that a variation in concentration of the electrolyte components and electrolysis parameters (current density and treatment time) provides the formation of oxide coatings consisting of the basic matrix materials and the cobalt oxides of different composition and morphology that are expected to affect their functional properties. Mixed oxide coatings formed in a plasma-electrolytic mode characterized by microglobular structure with reducing the conglomerate size have an increased abrasion and wear resistance and an intense catalytic activity. Thus, there is a prospect of using such coatings in the process of burning fuel in internal combustion engines and reduce the toxicity of emissions improving fuel efficiency and environmental performance of engines and in the industrial systems of catalytic purification of exhaust gases of industrial plants and power system facilities.
\end{abstract}

Keywords: AK12M2MgN alloy, plasma electrolytic oxidation, metal oxide system, cobalt oxides, mixed oxides, catalytic activity, corrosion resistance.

Рассмотрены принципы плазменно-электролитического оксидирования сплавов алюминия в дифосфатных электролитах. Показано, что варьирование концентрации компонентов электролита и параметров электролиза (плотности тока и времени обработки) способствует формированию оксидных покрытий, включающих матрицу основного металла и оксиды кобальта различного состава и морфологии, которые обусловливают их функциональные свойства. Сформированные в режиме плазменно-электролитного оксидирования смешанные оксиды, которые характеризуются микроглобулярной структурой и уменьшением размеров конгломератов, отличаются повышенными сопротивлением абразивному износу и износостойкостью, высокой каталитической активностью. Поэтому представляется целесообразным применение таких покрытий в рабочих процессах двигателей внутреннего сгорания для повышения их әффективности и уменьшения токсичных выбросов, а также в системах каталитической очистки газовых выбросов предприятий промышленного комплекса и энергетики.

Покриття зі змішаними оксидами кобальту і алюмінію для екологічної безпеки. М.В.Ведь, М.Д.Сахненко, Г.В.Каракуркчі, Т.Ю.Мирна.

Розглянуто принципи плазмово-електролітичного оксидування сплавів алюмінію у дифосфатних електролітах. Показано, що варіювання концентрації компонентів електроліту та параметрів електролізу (густини струму і часу обробки) сприяє формуванню оксидних покриттів, що включають матрицю основного металу і оксиди кобальту різного складу і морфології, які обумовлюють їхні функціональні властивості. Сформовані у режимі плазмово-електролітного оксидування змішані оксиди, які характеризуються мікроглобулярною структурою і зменшеними розмірами конгломератів, відрізняються підвищенними опором абразивному зношуванню й зносостійкістю та високою каталітичною активністю. Тому вбачається доцільним застосування таких покриттів у робочих процесах двигунів внутрішнього згоряння для підвищення їх ефективності i зменшення токсичних викидів, а також у системах каталітичного очищення газових викидів підприємств промислового комплексу і енергетики. 


\section{Introduction}

The widespread use of aluminum and alloys in various industries (air and mechanical engineering, medicine, chemical industry), and in innovative technologies puts forward a number of requirements for their corrosion resistance, mechanical strength, tribological characteristics, catalytic activity and other.

Environmental and technical problems arising in the operation of internal combustion engines (ICEs) are associated with the incomplete combustion of fuel and, accordingly, the inevitable formation of toxic components, such as $\mathrm{CO}, \mathrm{NO}_{x}$, and soot [1]. One of the possible ways to improve the performance of ICEs can be the use of catalysis in situ in the combustion chamber [2]. Since catalytic processes are characterized by a decrease in the activation energies of intermediate stages, the combustion process and complete fuel combustion occur at lower temperatures $(650-1200 \mathrm{~K})$. This feature must lead to a decrease in the maximum pressure in the combustion chamber and, hence, to the minimization of emissions of hazardous substances with exhaust gases when forced modes of engine operation.

The currently available hydrocarbon fuel combustion catalysts are divided into two groups: catalysts based on noble metals (most commonly $\mathrm{Pd}$ and $\mathrm{Pt}$ ) and transitionmetal oxides (Mn, Co, Fe, etc.), particularly those with a complex composition (spinels, perovskites, hexa-aluminates) [3]. At high temperatures, significant advantages are shown by a family of catalysts based on cobalt oxides, which exhibit high thermal stability and oxygen affinity [4]. The formation of non stoichiometry cobalt oxides not only provides the thermal stability of the catalysts but also leads to a significant improvement of the catalyst reactivity.

In terms of rational designing and effective technology, it seems appropriate to deposit a catalytic layer directly on the surface of ICE pistons manufactured using AK12M2MgN cast complex-alloyed silumins with an optimal combination of physic-mechanical and performance properties [5]. The most promising method for the formation of thin layers on passive-metal surfaces, in particular, silumins, is plasma electrolytic oxidation (PEO). This method provides the incorporation of catalytically active components into an alumina matrix owing to the implementation of both electrochemical and thermo-chemical reactions in high-energy modes [6, 7]. However, it should be taken into account that the PEO of silumins is a complicated process because these materials contain a large number of alloying components and intermetallic compounds with different chemical properties of their oxides. On the basis of the above, the main task that has predetermined the aim of this study is to substantiate the electrolyte composition and the PEO modes for the formation of a mixed oxide layer with high cobalt content on the surface of the AK12M2MgN alloy.

It is much interesting to consider studies that are aimed at improving the technologies of producing oxide coatings. However, a vast majority of traditional methods can not provide sufficiently strong adhesion, wear resistance and corrosion resistance combined with a certain set of properties appropriate for the functional materials utilization. The method of plasma electrolytic oxidation PEO, which is also called microarc or anode-spark oxidation, allows creating strong adhesion to the substrate of oxide coatings that have dielectric [8,9], protective [10], catalytic [11], anti-friction [12], and other properties [13-15].

A distinctive feature of the PEO method is the possibility to form conversion layers that incorporate both oxides of a refined metal and electrolyte components or products of their electrochemical and thermochemical transformations. The chemical composition of the coatings formed by PEO predetermined by the nature of the oxidizable metal, the process parameters, and the electrolyte components, so that controlling the chemical composition of anode layers can significantly improve their physical and chemical properties [11, 14] as well as significantly expand the functional uses of valve metals and their alloys.

The purpose of the work is to investigate the influence of PEO parameters on the composition, morphology and functional (catalytic, anti-friction, protective) properties of mixed oxides of aluminum and cobalt.

\section{Experimental}

The studies were conducted using A99 aluminum (impurities, wt. $\%$ : Si - 0.5; Fe - 0.5) and AK12M2MgN (AL25) alloy of composition, wt. \%: Si - 11.5-13.0; Cu $1.5-3.0 ; \mathrm{Ni}-0.8-1.3 ; \mathrm{Mg}-0.8-1.3 ; \mathrm{Mn}$ - 0.3-0.6; Fe $<0.8 ; \mathrm{Zn}<0.5 ; \mathrm{Ti}<0.2 ; \mathrm{Pb}$ $<0.1$; $\mathrm{Sn}<0.02$; $\mathrm{Cr}<0.2$. The samples had a working surface of $0.5 \mathrm{~cm}^{2}$. The surface preparation included sequential procedures 
of mechanical grinding, etching in an alkaline solution, thorough washing with distilled water, and drying.

Coatings formed in an electrolyte based on potassium diphosphate in the concentration of $0.1-1.0 \mathrm{~mol} / \mathrm{dm}^{3}$ with $\mathrm{CoSO}_{4}$ as additives. The pretreatment solutions and the oxidation diphosphate electrolytes were prepared from certified reagents graded as "chemically pure" and "analytical grade" with distilled water.

The anodic behavior of aluminum alloys in solutions of different compositions was studied by linear voltammetry at different polarization rates using an IPC Pro-M potentiostat. Polarization measurements were conducted in a standard thermostatic electrochemical cell at a temperature of $20 \pm 1^{\circ} \mathrm{C}$ using a cathode of AISI 304 stainless steel. The working electrolytes based on aqueous solutions of sodium hydroxide or potassium diphosphate with a concentration of $0.005-$ $1.0 \mathrm{~mol} \cdot \mathrm{dm}^{-3}$ were admixed with cobalt sulfate in a concentration range of $0.05-$ $0.20 \mathrm{~mol} \cdot \mathrm{dm}^{-3}$; the $\mathrm{pH}$ value was $10-12$. The electrode potentials were measured with respect to an EVL-1M1 silver-silver chloride reference electrode connected to the working cell through a salt bridge filled with a saturated solution of potassium nitrate thickened with agar-agar. The potentials given in this study were converted with respect to a standard hydrogen electrode (SHE).

The PEO of AK12M2MgN alloy was conducted using a B5-50 stabilized power supply that maintained voltage up to $300 \mathrm{~V}$. PEO was implemented in an electrolytic cell under conditions of forced cooling of the electrolyte to a temperature of $25-30^{\circ} \mathrm{C}$ and stirring the electrolyte. A current density varied in a range of $5-25 \mathrm{~A} \cdot \mathrm{dm}^{-2}$ for AK12M2MgN. Since the kinetics of the plasma electrolytic oxidation of metals can very significantly depending on the acidity of the electrolyte, an important element of the process was monitoring of the electrolytes $\mathrm{pH}$.

The chemical composition of the coatings was determined by X-ray photoelectron spectroscopy on an INCA Energy 350 energy dispersive spectrometer. X-ray radiation was excited via exposing the samples to a $15 \mathrm{keV}$ electron beam. In addition, X-ray fluorescence analysis was conducted using a SPRUT portable spectrometer with a relative standard deviation of $10^{-3}-10^{-2}$; the error in determining the component content was $\pm 1 \mathrm{wt} . \%$. The surface of the coatings was studied using a Zeiss EVO 40XVP scanning electron microscope (SEM). Images were recorded by the registration of secondary electrons (BSEs) via scanning with an electron beam; this mode made it possible to study the topography with a high resolution and contrast ratio.

The surface morphology and roughness of coatings were studied by an atomic force microscopy AFM using NT-206 microscope. Scanning was performed using the contact probe CSC-37 (lateral and vertical resolutions 2 and $0.2 \mathrm{~nm}$, respectively; $1024 \times 1024$ scanning matrix, CSC cantilever $B$ as probe, probe tip radius $10 \mathrm{~nm}$ ).

The catalytic properties of the oxide systems were studied in the oxidation of carbon (II) oxide to carbon (IV) oxide [15]. The studies were conducted on a laboratory bench in a tubular flow reactor made of silica glass with a coaxially wound heating coil. The initial mixture of air and carbon (II) oxide with a concentration of 1.0 vol. $\%$ was fed to a reactor with a volume of $1.5 \times 10^{-2} \mathrm{dm}^{3}$ at a rate of $1.5 \mathrm{dm}^{3} \cdot \mathrm{h}^{-1}$. The reactor temperature was gradually increased from 20 to $450^{\circ} \mathrm{C}$ at a rate of $1^{\circ} \mathrm{C} \cdot \mathrm{s}^{-1}$. The $\mathrm{CO}$ concentration at the inlet and outlet of the reactor was recorded using Dozor signaling-analyzing devices. The catalytic activity was evaluated by the following parameters: the initial temperature of the oxidation process (the ignition temperature, $T_{i}$ ) and the conversion extent $(X, \%)$. The extent of conversion was calculated by the following equation:

$$
X=\frac{c(\mathrm{CO})_{i}-c(\mathrm{CO})_{f}}{c(\mathrm{CO})_{i}} \cdot 100 \%,
$$

where $c(\mathrm{CO})_{i}$ and $c(\mathrm{CO})_{f}$ are the initial and the final concentrations of carbon (II) oxide, \% .

The abrasion rate for the materials $\Delta l / \Delta t$ was determined by the Calotte method on the calotester [16].

\section{Results and discussion}

The efficiency of the anodic oxidation of aluminum alloys containing transition metals or inter-metallic compounds $\mathrm{Al}-\mathrm{Cu}-\mathrm{Ni}$ and $\mathrm{Al}-\mathrm{Cu}-\mathrm{Mn}-\mathrm{Fe}$, in particular, AK12M2MgN, depends on the ratio between the electrical resistivity of oxides of the base metal and the alloying components [17]. Under conditions of local temperature gradients during PEO, the thermal resistance and temperature dependence of the electrical conductivity of the oxides become 
M.V.Ved et al. / Functional mixed cobalt and ...

Table 1. Characteristics of alloying metals oxides in AK12M2MgN

\begin{tabular}{|c|c|c|c|c|}
\hline \multirow[t]{2}{*}{ Metal } & \multirow[t]{2}{*}{ Oxide } & \multicolumn{2}{|c|}{ Electrical resistivity $(\Omega \cdot \mathrm{cm})$ at $T(\mathrm{~K})$} & \multirow[t]{2}{*}{ Thermal resistance } \\
\hline & & 293 & 1873 & \\
\hline $\mathrm{Al}$ & $\mathrm{Al}_{2} \mathrm{O}_{3}$ & $3 \cdot 10^{14}$ & $10-20$ & - \\
\hline $\mathrm{Si}$ & $\mathrm{SiO}_{2}$ & $10^{16}$ & 0.9 & - \\
\hline \multirow[t]{2}{*}{$\mathrm{Cu}$} & $\mathrm{CuO}$ & $10^{5}$ & & $\begin{array}{c}\rightarrow \mathrm{Cu}_{2} \mathrm{O}, 1324- \\
1398 \mathrm{~K}\end{array}$ \\
\hline & $\mathrm{Cu}_{2} \mathrm{O}$ & $1 \cdot 10^{4}-3 \cdot 10^{4}$ & & $\rightarrow \mathrm{Cu}, 2098 \mathrm{~K}$ \\
\hline \multirow[t]{5}{*}{$\mathrm{Mg}$} & $\mathrm{MgO}$ & $10^{14}$ & & - \\
\hline & $\mathrm{MnO}$ & $10^{9}-10^{12}$ & & - \\
\hline & $\mathrm{Mn}_{2} \mathrm{O}_{3}$ & $10^{5}$ & & $\begin{array}{c}\rightarrow \mathrm{Mn}_{3} \mathrm{O}_{4}, 1238- \\
1388 \mathrm{~K}\end{array}$ \\
\hline & $\mathrm{Mn}_{3} \mathrm{O}_{4}$ & $10^{4}-10^{5}$ & & $\rightarrow \mathrm{MnO}, 1858 \mathrm{~K}$ \\
\hline & $\mathrm{MnO}_{2}$ & $10^{-1}-2.8 \cdot 10^{-3}$ & & $\begin{array}{c}\rightarrow \mathrm{Mn}_{2} \mathrm{O}_{3}, 828- \\
883 \mathrm{~K}\end{array}$ \\
\hline \multirow[t]{3}{*}{$\mathrm{Fe}$} & $\mathrm{FeO}$ & $10^{5}-10^{8}$ & & $\rightarrow \mathrm{Fe}_{3} \mathrm{O}_{4}$ \\
\hline & $\mathrm{Fe}_{2} \mathrm{O}_{3}$ & $10^{5}-10^{8}$ & & $\begin{array}{c}\rightarrow 4 \mathrm{Fe}_{3} \mathrm{O}_{4}, 1498- \\
1688 \mathrm{~K} \\
\end{array}$ \\
\hline & $\mathrm{Fe}_{3} \mathrm{O}_{4}$ & $4 \cdot 10^{-3}$ & & $\rightarrow \mathrm{FeO},>1835 \mathrm{~K}$ \\
\hline $\mathrm{Ni}$ & $\mathrm{NiO}$ & $10^{13}-10^{15}$ & & $\rightarrow \mathrm{Ni},>1528 \mathrm{~K}$ \\
\hline $\mathrm{Zn}$ & $\mathrm{ZnO}$ & $(6-9) \cdot 10^{4}$ & & - \\
\hline
\end{tabular}

of special significance. Close level of these properties guarantee a uniform distribution of the components in the bulk and on the surface of the oxide matrix and the reproducibility of the results. However, the anodic oxidation of the multicomponent AK12M2MgN alloy is accompanied by the formation of oxides that exhibit not only different conductivity $[18,19]$ but also differentiated thermal stability (Table 1); this feature considerably limits the possibility of forming high-quality coatings of a specified composition.

Therefore, for the homogenization of the surface composition of the treated alloy, a diphosphate ion was introduced into the electrolyte as a ligand while the stability of the complexes with the main components of the alloy is fairly high [20].

Analysis the anodic behavior of the AK12M2MgN alloy and A99 aluminum in a potassium diphosphate solution suggests that the active dissolution of the inter-metallic compounds and the alloying components of the alloy begins at a potential of 1.2 V, whereas on the surface of pure aluminum, an oxide film is formed and no active process is observed in the studied potential range (Fig. 1a). Analysis anodic behavior of the AK12M2MgN alloy in a po- tassium diphosphate containing cobalt (II) (Fig. 2) reveals that the oxidation rate is lower an order of magnitude compared to the diphosphate electrolyte.

This difference may be attributed with variation in electrical resistivity and thermal stability of cobalt oxides (Table 2) formed on the AK12M2MgN surface at anodic oxidation.

Experimental data indicate that the oxidation current density increases with polarization rate and is virtually independent of the concentration of cobalt or diphosphate. Considering intensification of the PEO process in dilute solutions, mixed alumina and cobalt oxides were formed in electrolyte of composition $-0.4 \quad \mathrm{M} \quad \mathrm{K}_{4} \mathrm{P}_{2} \mathrm{O}_{7}, \quad 0.1 \mathrm{M}$ $\mathrm{CoSO}_{4}$.

The results of experimental studies found that $\mathrm{PEO}$ alloy AK12M2MgN in diphosphate electrolytes containing cobalt (II) is a classic case [6]. It was also established that PEO must be performed in the incident power mode. Initial current density $i_{0}$ is higher for forming barrier aluminum oxide film on the AK12M2MgN substrate, which is accompanied by oxidation of the alloying components and particularly silicon with forming soluble substances and promotes homogenization of the alloy surface. 


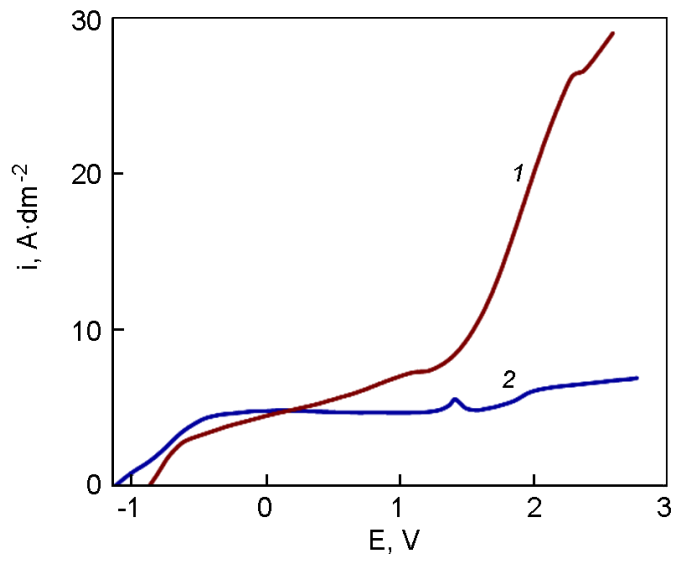

Fig. 1. Anodic voltammograms of the AK12M2MgN alloy (1) and A99 aluminum (2) in solutions of the composition, $\mathrm{mol} \cdot \mathrm{dm}^{-3}$ : $\mathrm{K}_{4} \mathrm{P}_{2} \mathrm{O}_{7}, 0.5$; potential scanning rate, $10 \mathrm{mV} \cdot \mathrm{s}^{-1}$; the potentials are given vs SHE.

After the process enters a mode of stable arcing current density for the following stages if is reduced to ensure a formation of the mixed oxide layer. The current density for the first $\mathrm{PEO}$ stage in cobalt-diphosphate solution does not exceed the interval 5-10 A.dm ${ }^{-2}$ (Fig. 3), while the second stage is advisable to hold at current qdensity of $2.0-4.0 \mathrm{~A} \cdot \mathrm{dm}^{-2}$. Characteristic voltage of $\mathrm{PEO}$ process also depends on the composition of the electrolyte: sparking voltage $U_{s}$ is $115-120 \mathrm{~V}$, and the resulting formation voltage $U_{f} 140-160 \mathrm{~V}$. It should be noted that all voltage parameters rising with the electrolyte dilution and with increasing current density. The cobalt content in the mixed oxides increases with the current density and uniformity of its distribution on the surface is improved. Composition of multicomponent oxides depends on both the concentration ratio of the electrolyte components and the oxidation current density. Thus, the oxide system is logically enriched with cobalt by increasing its content in the solution, but the electrolyte stability as well as service time is reduced. At the same time, increasing the diphosphate concentration in the bath is not desirable

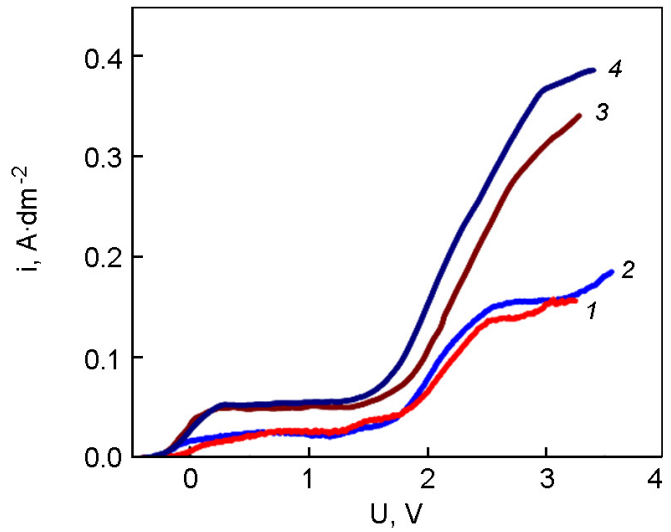

Fig. 2. Anodic voltammograms of the AK12M2MgN in solutions of the composition, $\mathrm{mol} \cdot \mathrm{dm}^{-3}:(1,3) \mathrm{K}_{4} \mathrm{P}_{2} \mathrm{O}_{7}, 0.2, \mathrm{CoSO}_{4}, 0.05$; $(2,4) \mathrm{K}_{4} \mathrm{P}_{2} \mathrm{O}_{7}, 0.4, \mathrm{CoSO}_{4}, 0.1$; potential scanning rate, $\mathrm{mV} \cdot \mathrm{s}^{-1}:(1,2) 10 ;(3,4) 50$; the potentials are given vs SHE.

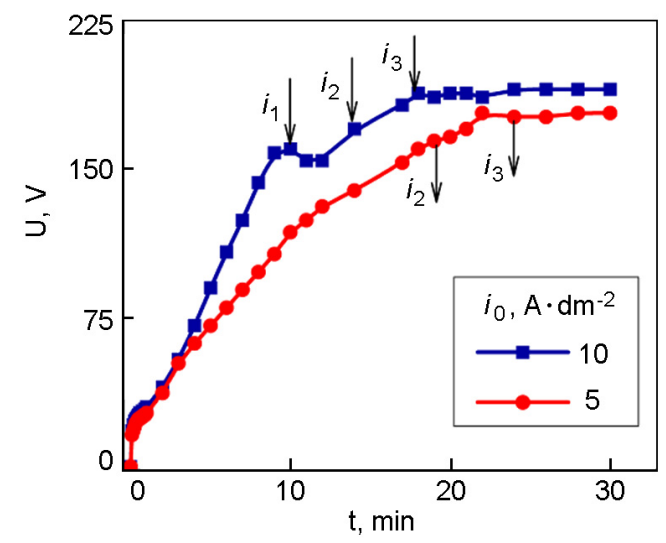

Fig. 3. PEO voltage chronograms in electrolyte $0.4 \mathrm{M} \mathrm{K}_{4} \mathrm{P}_{2} \mathrm{O}_{7}, 0.1 \mathrm{M} \mathrm{CoSO}_{4}$ at initial current density $i_{0}$ following by step current density $i_{f}, \mathrm{~A} \cdot \mathrm{dm}^{-2}: 4(1) ; 3$ (2); 2 (3)).

because it leads to a decrease of PEO efficiency.

Surface morphology and composition of PEO coatings doped with cobalt oxides depends both on the concentration of electrolyte and oxidation conditions - current density, voltage and time of formation (Fig. 4). The incorporation of the cobalt in

Table 2. Characteristics of Cobalt oxides

\begin{tabular}{|c|c|c|}
\hline Oxide & $\begin{array}{c}\text { Electrical resistivity }(\Omega \mathrm{cm}) \text { at } \\
293 \mathrm{~K}\end{array}$ & Thermal resistance \\
\hline $\mathrm{CoO}$ & $10^{6}-10^{10}$ & - \\
\hline $\mathrm{Co}_{2} \mathrm{O}_{3}$ & $10^{5}$ & $\rightarrow \mathrm{Co}_{3} \mathrm{O}_{4}, 538 \mathrm{~K}$ \\
\hline $\mathrm{Co}_{3} \mathrm{O}_{4}$ & $4 \cdot 10^{3}-(1.05-1.6) \cdot 10^{4}$ & $\rightarrow \mathrm{CoO}, 1178-1213 \mathrm{~K}$ \\
\hline
\end{tabular}




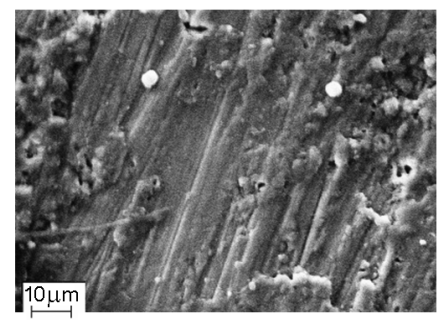

$\mathrm{Al}-40.5 ; \mathrm{O}-53.7$;

$\mathrm{Si}-5.4 ; \mathrm{Mn}-0.4 ; \mathrm{Cu}-0.1$

a)

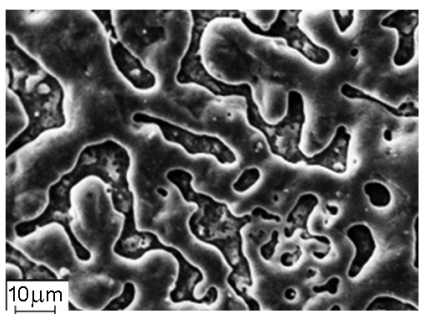

$\mathrm{Al}-33.3 ; \mathrm{Co}-8.7 ; \mathrm{O}-55.2$; $\mathrm{Si}-2.8$

b)

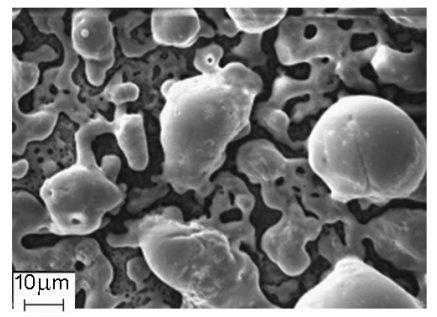

$\mathrm{Al}-28.7 ; \mathrm{Co}-23.6$;

$\mathrm{O}-45.9 ; \mathrm{Si}-1.8$

c)

Fig. 4. Surface morphology and composition (at.\%) of $\mathrm{PEO}$ coatings on $\mathrm{AK} 12 \mathrm{M} 2 \mathrm{MgN}$ : (a) $\mathrm{Al} \mid \mathrm{Al}_{2} \mathrm{O}_{3}$ obtained in electrolyte $0.4 \mathrm{M} \mathrm{K}_{4} \mathrm{P}_{2} \mathrm{O}_{7}$ with current density $i_{0}=8 \mathrm{~A} \cdot \mathrm{dm}^{-2}$; (b, c) mixed oxide systems $\mathrm{Al} \mid \mathrm{Al}_{2} \mathrm{O}_{3} \cdot \mathrm{CoO}_{x}$ obtained in $\mathrm{PEO}$ two stage mode $\left(i_{0}=8 \mathrm{~A} \cdot \mathrm{dm}^{-2}, i_{f}=2.5 \mathrm{~A} \cdot \mathrm{dm}^{-2}\right)$ in diphosphate electrolyte with $\mathrm{CoSO}_{4}$ addition of concentration, mol. $\mathrm{dm}^{-3}$ : (b) 0.05 ; (c) 0.2 . Magnification $\times 1000$.

oxide systems affects the formation of separate spheroid islets of characteristic bluepurple color. During the treatment the number of islet structures significantly increases, some the islets grow together, agglomerated and form a ceramic like mosaic patterns (Fig. 4b, c).

The higher content of cobalt the more developed but at the same time the less uniform becomes the surface of coating. Formed oxide systems have high developed micro globular surface with cobalt content 8-30 at. $\%$ and lower concentration of impurities comparing with $\mathrm{Al}_{2} \mathrm{Al}_{2} \mathrm{O}_{3}$ coating synthesized in pure diphosphate electrolyte (Fig. 4a), which is essential for the high catalytic properties of the material [3]. Analysis of the composition of oxide systems indicates nonstoichiometric ratio of cobalt and oxygen which is favorable for the implementation of catalytic processes involving oxygen.

It was established by AFM analysis that the surface of $\mathrm{Al} \mid \mathrm{Al}_{2} \mathrm{O}_{3} \cdot \mathrm{CoO}_{x}$ system with cobalt content of 8-12 at.\% (C3Fig. 5) is microglobular characterized by the high roughness and larger conglomerate sizes compared to the $\mathrm{Al} \mid \mathrm{Al}_{2} \mathrm{O}_{3}$. Mixed oxide coatings are composed from the set of spheroid conglomerates with an average size of 1-2 $\mu \mathrm{m}$ which gather and form the parts of smooth surface with the spherical agglomerates of 6-8 $\mu \mathrm{m}$ (Fig. 5a). The surface roughness may be characterized with the spread of conglomerate size on the cross section between markers 1-2 (Fig. 5b). In addition, the surface morphology of oxides is characterized by rather large difference between hills and valleys (Fig. 5c) of $0.3 \mu \mathrm{m}$
Table 3. Characteristics of the CO conversion to $\mathrm{CO}_{2}$

\begin{tabular}{|c|c|c|c||}
\hline Material & $\begin{array}{c}\text { Active } \\
\text { metal } \\
\text { content, } \\
\text { at. } \%\end{array}$ & $\begin{array}{c}\text { Ignition } \\
\text { temperature } \\
T_{i}, \mathrm{~K}\end{array}$ & $\begin{array}{c}\text { Complete } \\
\text { conversion } \\
\text { temperature } \\
T_{c}, \mathrm{~K}\end{array}$ \\
\hline $\mathrm{Pt}$ & 100 & 490 & 570 \\
\hline $\mathrm{Al} \mid \mathrm{Al}_{2} \mathrm{O}_{3}$ & 30.8 & 595 & 670 \\
\hline $\mathrm{Al} \mid \mathrm{Al}_{2} \mathrm{O}_{3} \cdot \mathrm{CoO}_{x}$ & 8.7 & 505 & 580 \\
\hline
\end{tabular}

up to $1.2 \mu \mathrm{m}$, and alternating the spheroid and torus-shaped structures (Fig. 4c).

Thus the anodic oxidation of the AK12M2MgN cast aluminum alloy as the main structural material of ICEs is complicated by the presence of significant amounts of alloying elements, such as silicon, copper and iron subgroup metals. Therefore, satisfactory-quality coatings of a considerable thickness can be obtained only in the PEO mode. A variation in the ratio between diphosphate and cobalt $(2+)$ ions leads to a variation in the sparking and forming voltage in PEO. This feature makes it possible to control the process and prepare more perfect oxide coatings resistant to local overheating. An increase in the coating thickness and the cobalt oxide content in the coating are achieved by the homogenization of the treated surface owing to the parallelization of the anodic process that provides the simultaneous formation of mixed oxides and the dissolution of the alloying components of the alloy.

Mixed oxide systems $\mathrm{Al}_{2} \mathrm{O}_{3} \cdot \mathrm{CoO}_{x}$ with cobalt content of 8-30 at. $\%$ were obtained on AK12M2MgN by two step plasma-electrolytic oxidation in a diphosphate electrolyte added 

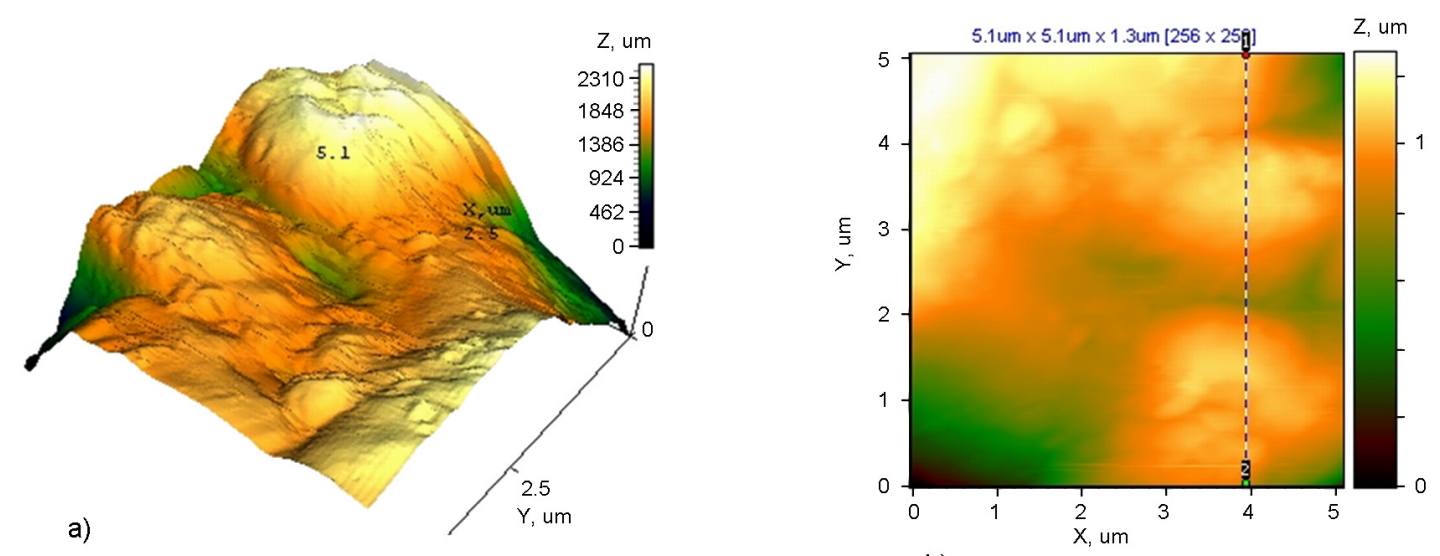

b)

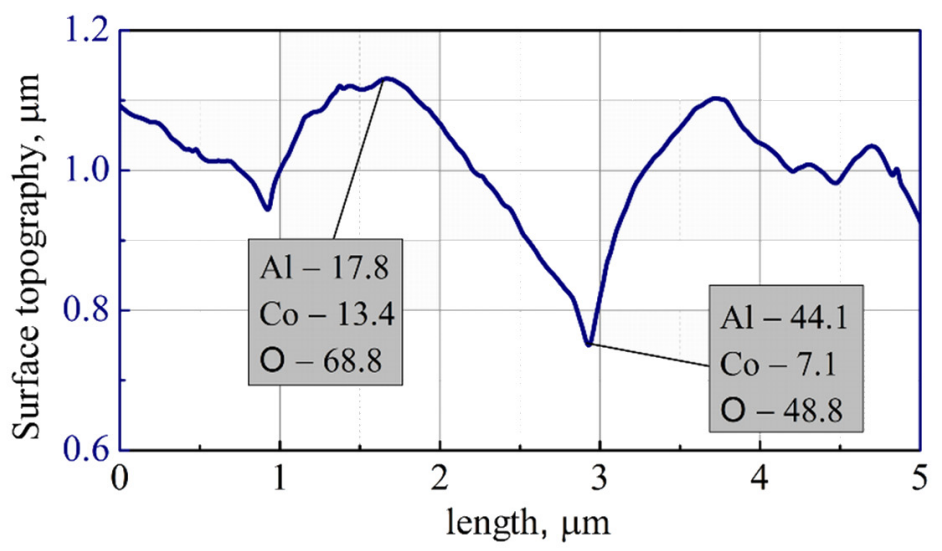

c)

Fig. 5. 3D (a) and 2D (b) maps of the surface and cross section profile (c) between markers 1 and 2 for mixed oxide system $\mathrm{Al}_{\mid} \mathrm{Al}_{2} \mathrm{O}_{3} \cdot \mathrm{CoO}_{x}$ with Cobalt content 8.7 at. $\%$. Scanning area $5 \times 5 \mu \mathrm{m}$.

with cobalt (II) sulfate. It has been found that surface concentration of silicon dopant in mixed coatings is two to three times less than in the system $A \| \mathrm{Al}_{2} \mathrm{O}_{3}$ or initial alloy. It was shown nonstoichiometry ratio of cobalt and oxygen in deposits as well as that the cobalt content in mixed oxide increases regularly with concentration of cobalt ions in the electrolyte. At the same time the morphology of $\mathrm{Al} \mathrm{Al}_{2} \mathrm{O}_{3} \cdot \mathrm{CoO}_{x}$ surface changes from the uniformly roughened to micro globular containing sufficiently large spheroids characterized by elevated concentrations of cobalt. Taking into account relief of $\mathrm{Al} \mathrm{Al}_{2} \mathrm{O}_{3} \cdot \mathrm{CoO}_{x}$ as well as the composition of the oxide coatings, one can reasonably expect that the resulting materials will exhibit catalytic activity in redox reactions involving oxygen $[4,15]$.

Testing of oxide system in the model reaction of carbon (II) oxide conversion to $\mathrm{CO}_{2}$ showed (Table 3 ) that their activity (both ignition and complete conversion temperature) is close to platinum catalyst.

This can be attributed to several factors: firstly due to a high affinity of non- stoichiometric cobalt oxides to oxygen and the corresponding decrease in the activation energy of double bonds $\mathrm{O}=\mathrm{O}$ destruction $[11,21]$. Secondly, the developed micro globular surface of oxide systems is characterized by a large number of catalytic centers and provides an increase in the number of elementary collisions and interactions.

Pilot tests of mixed oxides deposited on the surface of combustion chambers piston of the ICE, showed a reduction in fuel consumption at $1-3 \%$ and $\mathrm{NO}_{x}$ emissions reduction at forced diesel engine operating modes. This is due to lower the ignition temperature of the air-fuel mixture on the surface of $\mathrm{Al} \mid \mathrm{Al}_{2} \mathrm{O}_{3} \cdot \mathrm{CoO}_{x}$ catalyst composed of non-stoichiometry oxides with developed surface.

Abrasion resistance and mechanical strength of the material are important parameters that are predetermined by not only the composition but also the surface morphology. Perhaps wear resistance is provided mainly by aluminum oxide modifications $\gamma$ - and $\alpha-\mathrm{Al}_{2} \mathrm{O}_{3}$ and $\mathrm{CoO}_{x}$. Abrasion 
rate $(\Delta l / \Delta t)$ for $\mathrm{Al} \mathrm{Al}_{2} \mathrm{O}_{3}$ coatings on $\mathrm{AK} 12 \mathrm{M} 2 \mathrm{MgN}$ (Fig. 4a) is indicated as $0.1 \mu \mathrm{m} \cdot \mathrm{h}^{-1}$ and decreases up to $0.03 \mu \mathrm{m} \cdot \mathrm{h}^{-1}$ for the mixed oxide systems $\mathrm{Al}_{2} \mathrm{Al}_{2} \mathrm{O}_{3} \cdot \mathrm{CoO}_{x}$ with micro globular structure of the surface (Fig. 4b). Simultaneously increasing the content of cobalt, and as a result, a significant increase in the size of the globules leads to increased abrasion wear $0.05 \mu \mathrm{m} \cdot \mathrm{h}^{-1}$ (Fig. 4c).

Thus we can conclude that the varying electrolyte concentration and conditions of the PEO process allows formation of oxide coatings of different composition and morphology that are expected to affect their functional properties including abrasion resistance and catalytic activity in the process of burning fuel in internal combustion engines. These reduce the toxicity of emissions, improving fuel efficiency and environmental performance of engines.

\section{Conclusions}

Mixed oxide systems $\mathrm{Al}_{2} \mathrm{O}_{3} \cdot \mathrm{CoO}_{x}$ with cobalt content of $8-30$ at. $\%$ were obtained on aluminum alloy by two step plasma-electrolytic oxidation in a diphosphate electrolyte added with cobalt(II) sulfate. It has been found that surface concentration of silicon dopant in mixed coatings is two to three times less than in the system $A|| A_{2} \mathrm{O}_{3}$ or treated alloy.

It was shown nonstoichiometry ratio of cobalt and oxygen in deposits as well as that the cobalt content in mixed oxide increases regularly with concentration of cobalt ions in the electrolyte. At the same time the morphology of $\mathrm{Al} \mid \mathrm{Al}_{2} \mathrm{O}_{3} \cdot \mathrm{CoO}_{x}$ surface changes from the uniformly roughened to micro globular containing sufficiently large spheroids characterized by elevated concentrations of cobalt. Because of this mixed PEO systems with cobalt content about 10 at. $\%$ have a high wear resistance.

Obtained mixed oxide systems have developed surface with alternating the spheroid and torus-shaped structures which is associated with a large number of catalytic sites. They exhibit catalytic behavior in the model reaction of $\mathrm{CO}$ conversion to $\mathrm{CO}_{2}$ not inferior to the contacts with noble metals. The coatings $\mathrm{Al}_{2} \mathrm{O}_{3} \cdot \mathrm{CoO}_{x}$ contribute to fuel economy and improve the environmental performance of the internal combustion engine thus can be recommended for use in the neutralization of gas emissions systems and as coatings for pistons of combustion chamber.

\section{References}

1. W.C.Gardiner, Combustion Chemistry, Springer-Verlag, New York (1984).

2. K.F.Fong, C.K.Lee, Appl.Energy, 160, 793 (2015).

3. A.B.Stiles, Catalyst Supports and Supported Catalysts: Theoretical and Applied Concepts. Butterworth, Stoneham, MA (1987).

4. N.D.Sakhnenko, M.V.Ved, Yu.V.Vestfrid, I.I.Stepanova, Zh. Prikladnoi Khimii, 69, 9 (1996).

5. M.V.Glazoff, V.S.Zolotorevsky, N.A.Belov, Casting Aluminum Alloys, Elsevier, Oxford (2007).

6. N.D.Sakhnenko, M.V.Ved', D.S.Androshchuk, S.A.Korniy, Surf.Engin.Appl.Electrochem., 52, 2 (2016).

7. M.V.Ved', N.D.Sakhnenko, O.V.Bogoyavlenska, T.O.Nenastina, Mater. Sci., 44, 1 (2008).

8. A.L.Yerokhin, X.Nie, A.Leyland, S.J.Dowey, Surf. Coat. Technol., 122, 2 (1999).

9. V.S.Rudnev, I.V.Lukiyanchuk, M.S.Vasilyeva, N.V.Sergienko, Surf.Coat.Technol., 307, Part C (2016).

10. P.Gupta, G.Tenhundfeld, E.O.Daigle, D.Ryabkov, Surf. Coat.Technol., 201, 21 (2007).

11. N.D.Sakhnenko, M.V.Ved, F.V.Karakurkchi, A.V.Galak, East. Europ. J. Enterprise Technol., 3, 5(81) (2016)

12. L.R.Krishna, K.R.C.Somaraju, G.Sundararajan. Surf.Coat.Technol., 163-164, 484 (2003).

13. O.P.Terleeva, V.I.Belevantsev, A.I.Slonova, Prot. Met, 42, 278 (2006).

14. N.D.Sakhnenko, O.A.Ovcharenko, M.V.Ved', Zh. Prikladnoi Khimii, 88, 267 (2015).

15. M.Glushkova, T.Bairachna, M.Ved, M.Sakhnenko, MRS Proceedings, 1491 (2013).

16. A.Kassman, S.Iacobson, L.Ericson et al., Surf. Coat. Technol., 50, 1 (1991).

17. J.Mchardy, F.Ludwig, Electrochemistry of Semiconductors and Electronics: Processes and Devices, Noyes, New Jersey (1992).

18. A.Pergament, G.Stefanovich, V.Malinenko, A.Velichko, Adv. Condens. Matter. Phys., 1 (2015).

19. V.Patil, P.Joshi, M.Chougule, S.Sen, Soft Nanosci. Lett., 2, 1 (2012).

20. L.G.Sillen, A.E.Martell, J.Chem.Educ., 42, 9 (1965).

21. P.V.Snytnikov, V.D.Belyaev, V.A.Sobyanin, Kinet. Catal., 48, 1 (2007). 